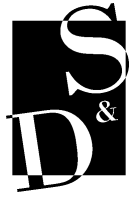

\title{
'You come back fighting. That's what gives you the drive to achieve': The extraordinary psychological construction of the super-rich in entertainment documentaries
}

Discourse \& Society

$1-16$

(c) The Author(s) 2021

(c) (i)

Article reuse guidelines: sagepub.com/journals-permissions DOI: I0.1 I77/095792652II0I31I7

journals.sagepub.com/home/das

@SAGE

\section{Philippa Carr}

University of the West of England, UK

\section{Simon Goodman}

De Montfort University, UK

\section{Adam Jowett \\ Jackie Abell \\ Coventry University, UK}

\begin{abstract}
Inequality in society is legitimised through the 'meritocracy myth' and existing research claims that the affluence of the super-rich is the result of their superior traits. Discursive Social Psychology examines the ways in which psychological concepts such as personality traits function in talk. This research explores how entertainment documentaries construct the traits of the super-rich to legitimise their wealth. A corpus of 41.5 hours of terrestrial UK televised broadcasts that used the term, 'super-rich' was analysed. This explored how wealthy individuals are presented as having superior psychological qualities compared to the general public in relation to their greater drive and resilience. However, wealthy individuals also talk about the development of superior
\end{abstract}

\section{Corresponding author:}

Philippa Carr, University of the West of England, Frenchay Campus, Coldharbour Lane, Bristol, BSI6 IQY, UK. Email: philippa2.carr@uwe.ac.uk 
traits as a response to adversity. Entertainment documentaries draw upon individualistic ideology to present wealth inequality as a natural consequence of individual differences and as a result, the current distribution of wealth is 'just' despite its negative consequences for all.

\section{Keywords}

discourse analysis, discursive social psychology, distribution of wealth, documentaries, entertainment, ideology, inequality, meritocracy, super-rich, traits, wealth

\section{Introduction}

This paper provides a critique of the definition, measurement and use of traits to explain wealth inequality in society. Given the socially constructed nature of traits, this research examines how super-rich individuals use psychological talk about their individual traits to legitimise their wealth. It was found that super-rich individuals present themselves as having increased resilience and drive to account for their extreme wealth acquisition. Speakers talk draws upon individualistic ideology to present themselves as deserving of their privilege. Additionally, just world arguments are used to present others as accountable for their status as they lack the work ethic of the super-rich.

Psychological research is used to legitimise the privileged position of wealthy individuals. In particular, economic inequality in society and the status of wealthy individuals have been explained through psychological research into individual differences (Hunt, 2004). Explanations for differences in individual economic status draw upon the concept of traits (Iatridis and Fousiani, 2009). For example, it has been claimed that the top $1 \%$ of wealthy individuals have higher intelligence levels than the financially less well-off (Wai, 2014). This could be perceived to be reflective of a meritocratic environment where increased affluence is due to a person's traits as opposed to external factors such as their socio-economic status at birth (Smith and Skrbiš, 2017). The term 'meritocracy' was devised by Young (1958) as part of his satirical critique of the British educational system. However, some researchers claim the term's meaning has become positive as meritocratic societies are presented as being fairer (Allen, 2011). Yet, McNamee et al. (2014) identified a 'meritocracy myth' that allows meritocratic ideology to perpetuate inequality and blame the poor for their circumstances. Given the negative impact of economic inequality on social issues such as health, education and crime (Wilkinson and Pickett, 2010) and the existence of a meritocratic state being deemed a myth, there is a need for an improved understanding of how meritocratic ideology is constructed and used to support wealth inequality in society.

\section{Critique of individual differences approach to wealth}

The use of individual differences research to legitimise inequality is questionable particularly as it ignores the social historical construction of traits. This results in the wealthy and poor being perceived to have differing traits (Leahy, 1981). Meritocratic ideology explains wealth inequality as the result of individual differences in people's abilities. However, there are limitations to the concept of traits, which casts doubts on their ability to explain inequality. Controversial research such as Eysenck's (1975) has 
made claims regarding the relationship between socio-economic status and intelligence. These claims persist as researchers claim that Eysenck's findings have been proven through the use of modern techniques demonstrating that children from lower socioeconomic status households have lower general intelligence scores (Gottfredson, 2016). However, Rickett (2020) critiques Gottfredson (2016) for using father's occupation as a measure of socio-economic status and for using an unrepresentative sample of White boys to form wider generalisations. Burr (2015) states that traits have not been used across time and cultures to explain personality. As socially constructed concepts traits are not solely internal and require individuals to draw upon shared knowledge. Individual difference measures draw upon ideology to present poorer groups as deficient and lesser (Day et al., 2014). The presentation of traits as objective ignores their social construction and use to account for inequality.

Resilience is a trait that is related to a person's ability to achieve that can be related to their socio-economic status (Dirzyte et al., 2017). Resilience has been used increasingly in research post the 2008 Global Financial Crisis (Robertson and Cooper, 2013). In its everyday usage, resilience is defined as the 'capacity to recover from misfortune' (Oxford English Dictionary, 2010). One definition of resilience used in research is a measure of successful stress-coping ability (Connor and Davidson, 2003). Grant et al. (2009) claimed that resilience resulted in improved achievement in the workplace for senior employees. In contrast, poorer groups are constructed as being irrational with problematic cognition and poor practices (Day, 2020). Given the emphasis placed on resilience in research on performance and social mobility, there is a need to consider how this is constructed in relation to the super-rich and their acquisition of wealth.

A further trait claimed to be related to an individual's socio-economic status is motivation (Snibbe and Markus, 2005). Like resilience, there is some ambiguity regarding its definition in research (Vansteenkiste and Mouratidis, 2016) and this continues into its everyday definition where motivation is synonymous with drive as a concept (Oxford English Dictionary, 2010). Wai (2014) argues that the super-rich have more drive than others. Unlike the super-rich, poorer groups such as the working class are presented as helpless and requiring intervention (Rickett, 2020). The ambiguity present in defining resilience and its effects provides an opportunity to explore how the super-rich use talk about resilience to legitimise their position.

Trait research ignores their social historical construction and how individual differences draw upon individualistic ideology to account for inequality; a wider social issue that needs to be addressed collectively. Given the social historical construction of individual differences in psychological research, the superiority of the more affluent can be seen to be a reflection of everyday assumptions in society (Iatridis and Fousiani, 2009). Research that alleges the superior traits of the super-rich does not acknowledge the detrimental impact poverty has on educational attainment or the access wealthier individuals have to greater educational opportunities. Attempts to correlate traits with wealth are affected by the separation of the trait from its external environment (Zhao et al., 2016) and resonates with the difficulties in separating low socio-economic status from intelligence as mentioned previously. Therefore, individual difference models of wealth are limited due to the lack of recognition of their social historical construction and attempts at measurement that do not acknowledge their wider social context. This results in trait 
approaches being influenced by dominant ideology that reflects existing economic inequality and acts as a resource to maintain the status quo.

The bias inherent in the definition and measurement of traits means that their use is flawed particularly as they over-emphasise the role of the individual in the acquisition of wealth. Stagnating social mobility is claimed to be the result of poor people lacking the required traits to gain wealth and not the result of a flawed meritocracy. Individual difference models are part of the psychologisation of society defined as the 'dissemination of the language of psychology into everyday life' (De Vos, 2008: 2). The pervasiveness of trait approaches in lay discourse requires a discursive approach to explore how talk about resilience and drive are used.

\section{Discursive social psychology and the construction of the super-rich in the media}

Using Discursive Social Psychology (DSP) (Wetherell, 1998) allows for the examination of how psychological talk about the wealthy draws upon individualistic ideology. DSP brings together Discursive Psychology (Edwards and Potter, 1992) and Rhetorical Psychology (Billig, 1991) to allow for the examination of how talk is situated and draws upon ideology. The influence of Discursive Psychology places a focus on how individuals use language as a form of social action, and the construction of psychological concepts (Edwards and Potter, 1992) such as traits. Discursive approaches view media products as a form of social action that requires audiences to draw upon their shared knowledge (Abell and Stokoe, 2001). Speakers preform social actions such as presenting their own or others identities through constructing subject positions within their talk (Davies and Harré, 1990). A discursive and rhetorical approach explores how talk is situated and draws upon differing ideology exploring how interpretative repertoires are used (Edley and Wetherell, 1997). Interpretative repertoires have been described as the 'building blocks' of talk, formed of everyday assumptions and are used to construct accounts (Wetherell and Potter, 1988: 172). Therefore, DSP is able to focus on participants orientations and the wider context that their talk is situated within. Wealth porn documentaries analysed using a discursive and rhetorical approach were found to draw upon neoliberal ideology to present extreme wealth as mundane (Carr, 2020). Within these programmes, dominant neoliberal ideology is challenged by the use of strategic ambiguity (Condor et al., 2013) created through the editing process. Therefore, DSP provides an opportunity to explore the construction of psychological differences in the presentation of the superrich in entertainment documentaries.

Discursive and rhetorical approaches acknowledge the role of ideology in talk and its role in maintaining inequality in broadcast media (Carr, 2020). For example, previous discursive research has demonstrated how individualism is pervasive in talk about wealth, particularly when arguing against high tax rates (Carr et al., 2019). Such individualism presents wealth as being solely earned and ignores the role that the state (and public spending from taxation) has played in creating the economic conditions for their wealth. Goodman and Carr (2017) offered a discursive re-evaluation of Lerner's (1980) concept of 'belief in a just world' (p. 11) showing how Just World arguments were drawn upon to justify inequality. Individuals utilise Just World arguments to legitimise limited 
redistribution in the form of welfare benefits (Goodman and Carr, 2017). These arguments use Just World ideology to justify inequality in society on the basis of economic productivity. This results in unemployment benefits being presented as unfair to workers. This argument, holds individuals to account as opposed to market conditions. In addition to this, rhetoric about individual responsibility legitimises the monitoring of unemployed people's search for employment. This use of individualistic discourse is also present in talk about tax where inequality is warranted as normal and the product of individual effort (Carr et al., 2019). Thus, individualistic ideology underlines talk about wealth inequality in society and positions individuals as responsible for their economic status. From this perspective, talk about individual differences becomes a discursive resource to draw upon in rhetoric legitimising inequality. In this study we draw on DSP to explore how super-rich individuals account for their extreme wealth through talk about their individual traits and how their discourse draws upon individualistic ideology to legitimise their privilege.

\section{Method}

\section{Data}

The data was gathered from 41.5 hours of free to air UK television broadcasts during 2016 featuring the term, 'super-rich'. The corpus is indicative of the rise of televised programming of what has been termed 'wealth porn' (Poole, 2000), that is the affluent opposite of the 'poverty porn' genre which has been criticised for its negative portrayal of benefit claimants (Hester, 2014). Due to the directly inaccessible nature of the superrich (Urry, 2014), the wealth porn genre provides an indirect opportunity to explore how the super-rich are presented by the media in society and how super-rich individuals publicly account for extreme levels of wealth.

\section{Analytic procedure}

The analysis used a DSP influenced Discourse Analysis framework to focus on the use of psychological concepts, ideology and management of accountability in talk. First, the data were transcribed using a basic notation that is consistent with critical forms of discursive and rhetorical approaches (Wiggins, 2017). Additional notations were added to reflect the edited nature of the programmes including the use of italic font to indicate the use of a voiceover (see Appendix). Where extracts involving splicing two parts of footage together, ((present)) indicates that the footage is presented as current whilst ((later)) is used for footage constructed as being filmed at a later date. Next, examples in the corpus that involved talk stating psychological concepts were identified and examined for how this was used by speakers. In the third stage, a focus was placed on how speakers accounted for their wealth acquisition. In particular, this centred on how talk using psychological concepts and interpretative repertoires were used by speakers to manage their accountability for being super-rich. Further analysis examined how the programmes draw upon ideology to construct the super-rich and account for their extreme wealth. 


\section{Findings}

In the programmes analysed, super-rich individuals present themselves as psychologically superior as a result of their enhanced resilience and drive. The extraordinariness of the super-rich in talk about themselves positions them as deserving of their status. Yet, speakers also present super-rich status as accessible to all if they are effortful enough. This involves the use of individualistic ideology such as a just world to legitimise inequality as others are deserving of their diminished status.

The following extract involves Eamonn Holmes (E) and Ruth Langsford (R) as presenters talking to Rodger Dudding (RD) a super-rich inventor, about his work practices as he shows them his car collection. This was featured on Eamonn and Ruth: How the Other Half Lives (series one, episode three), a Channel 5 series where Eamonn and Ruth examine the lifestyles of the super-rich. By referring to the top $1 \%$ of people with wealth as the 'other half', the programme's title downgrades the skew of wealth distribution in the UK. Ruth is sat in the backseat of one of Rodger's classic cars and Eamonn is stood by the car on Ruth's side. This following extract considers how the super-rich present themselves as being psychologically superior to others.

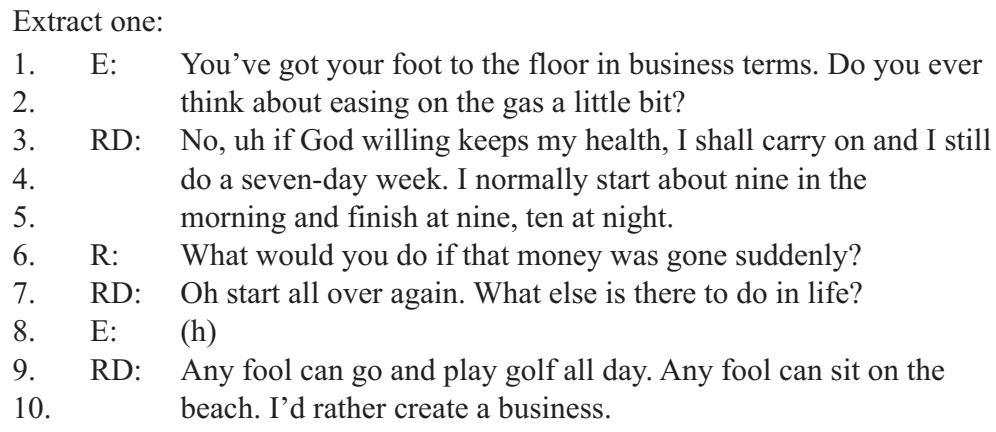

Eamonn constructs Rodger as being extremely effortful ('You've got your foot to the floor' (1)). Rodger builds on Eamonn's presentation of his level of activity as having a superior level of drive ('I still do a seven-day week' (3-4)) that is conditional on his health. The use of 'still' presents this as sustained behaviour that allows Rodger to address Eamonn's question which suggests his work practices are unnecessary ('Do you ever think about easing on the gas a little bit?' (1-2)). Rodger notes his own super-rich status as being the result of his own motivation and superior drive in his response to being asked by Ruth ('What would you do if that money was gone suddenly?' (6)). Rodger highlights the importance of being motivated to be economically productive in his response ('What else is there to do in life?' (7)). He presents himself as psychologically superior in comparison to other groups and their leisure activities ('Any fool can go and play golf all day' (9)). The term 'fool' allows Rodger to present himself as outstanding as a result of his ability to be successful in business which requires not only his increased drive but also his superior intelligence as he is not a 'fool'. The editing of this interview involves the presenter's reactions and in particular, that of Eamonn's laughter (8), to this comment. An everyday assumption about laughter is that it is a positive response. However, laughter 
can be used to undermine individuals (Billig, 2005) and in this situation offers the contrast of Rodger's superior drive to others who spend their time engaging in leisure activities. The featuring of Rodger results in the super-rich being constructed as having superior drive that is not presented as part of the psychological construction of other groups.

Rodger presents himself as having more drive than others which results in him being more economically productive. Through Rodger constructing himself as more driven and not interested in leisure activities, he uses this talk to accentuate himself as having a superior work ethic. The super-rich individuals featured use talk about their drive to legitimise their wealth. In The Millionaire's Gift Guide a one-hour documentary broadcast on BBC2, Tom Bolt (TB), a watch dealer is selling his Rolls Royce Phantom to Trevor Eve (TE), an actor. Tom's talk about his drive to acquire wealth allows for the exploration of how he justifies his status. The extract involves two separate clips spliced together, one featuring Tom selling the car to Trevor and the other filmed later with Tom talking directly to the camera.

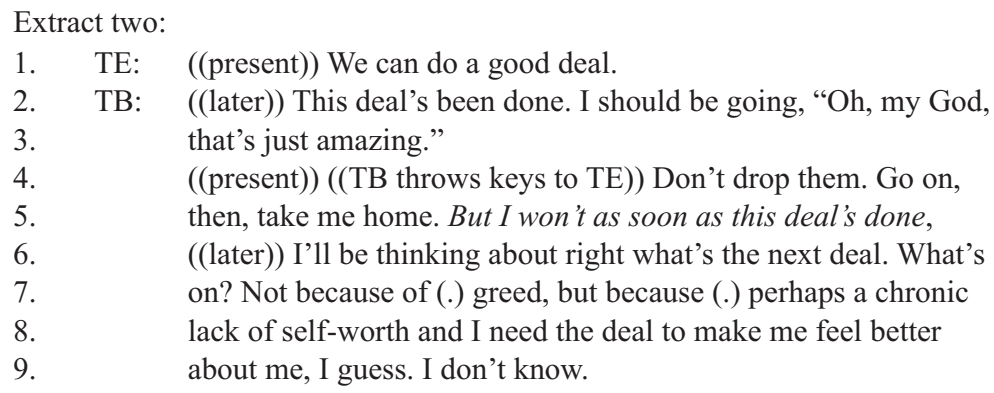

Similar to the previous extract, Tom presents himself as more driven. A contrast is provided in this extract between Tom's business activities and the psychological construction of himself that involves humour when negotiating the car deal (4). He uses a footing (Goffman, 1981) to present a rhetorical commonplace (Billig, 1987), a more typical level of motivation as experienced by others ('I should be going, "Oh, my God, that's just amazing"" (2-3)). The use of separate footage with Tom talking directly to the camera in a confessional style to the audience is used to emphasise Tom's negative presentation of himself as having superior levels of motivation. This footage is followed by Tom and Trevor constructing a humorous exchange as Trevor pretends to drop the car keys (4) that contrasts with the negative construction of Tom's personality. Unlike extract one, where laughter is used to challenge Rodger's talk about his superior work ethic, here humour is used to present Tom more positively as a likeable person who can engage in banter with others. The use of humour further emphasises the contrast used by Tom to present himself as being more motivated ('But I won't as soon as this deal's done, ((later)) I'll be thinking about right what's the next deal (5-6))'. This helps to manage Tom's accountability for his enhanced wealth in an unequal society ("Not because of (.) greed, but because (.) perhaps a chronic lack of self-worth' (7-8)). This involves the use of double declaiming (Billig, 1992) as Tom warrants the drive that allows him to maintain his wealth as having an undesirable foundation through the negative construction of his 'self-worth' (8). Tom uses 'stake inoculation' (Potter, 1996: 125) to orient to potential 
criticism about greed as an explanation for his increased drive particularly when supported by his alternative presentation as a likeable person through the editing of this extract. This allows Tom to dismiss everyday assumptions about the super-rich being greedy. For example, the use of 'I don't know' (9) presents Tom as unclear about the origin of his drive and can be oriented to challenge potential criticism. Earlier in the extract his deal making activities are presented as being positive through the construction of his perception of others' views of his work and Trevor and Tom's humour. Tom's talk about his drive provides a negative psychological construction that legitimises his wealth.

In addition to being presented as having increased drive, super-rich individuals work to present themselves as having superior levels of resilience to others. Featured on Eamonn and Ruth: How the Other Half Lives (series one, episode three), Kate Stewart (K), a businesswoman talks to Eamonn Holmes (E) and Ruth Langsford (R) about her background and image in a $£ 1000$ suite in the $\mathrm{W}$ hotel, London after a segment with Ruth where Kate tries on new outfits. This extract considers how the super-rich use their discourse to account for their wealth through the presentation of their increased resilience.

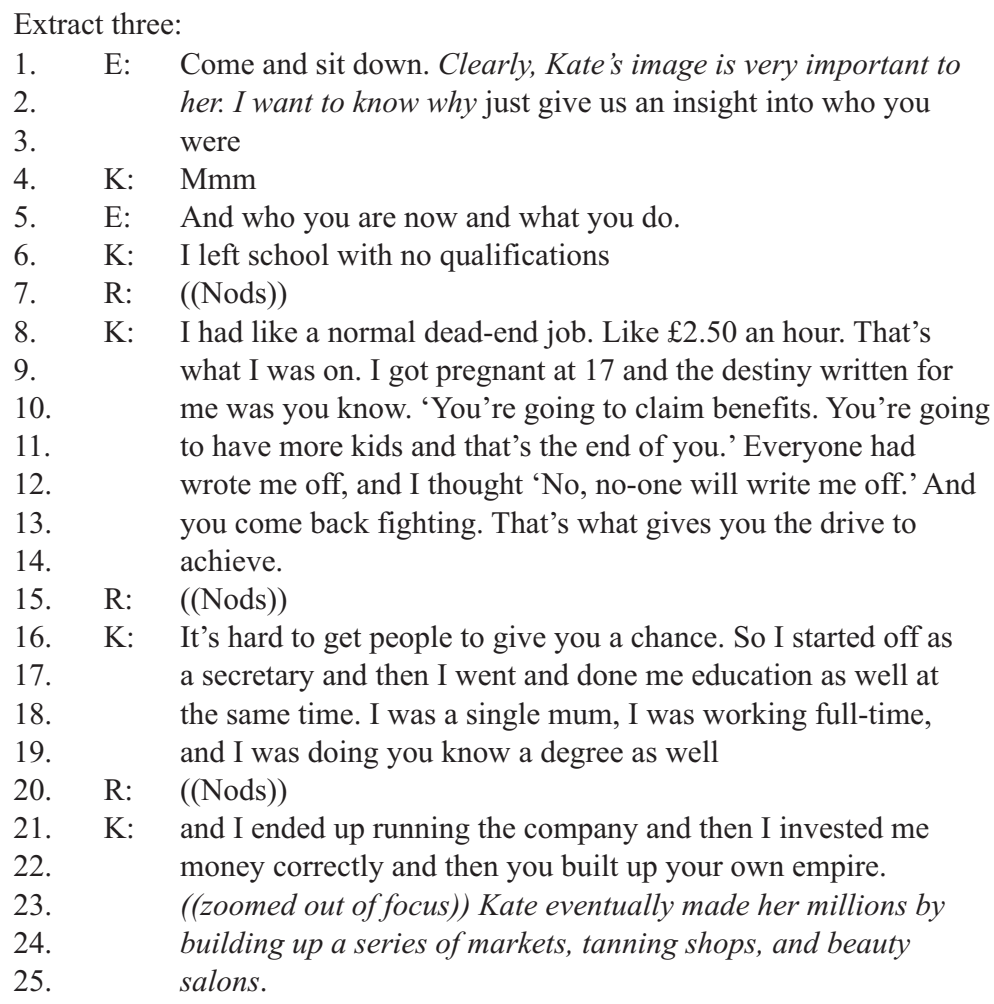

Kate uses her talk to present her resilience and drive as internal forces that allowed her to become socially mobile. Her response involves recounting her past circumstances when she was not wealthy ('I left school with no qualifications' (6)). Kate presents her previous lifestyle as being both conventional and negative, 'normal dead-end job' (8). Reported 
speech is used to position her previous social status (Leudar and Antaki, 1996) as a single parent on a low income ('You're going to claim benefits. You're going to have more kids and that's the end of you' (10-11)). Kate's talk involves the use of psychological language as she discusses her cognition ('I thought "No, no-one will write me off'. And you come back fighting. That's what gives you the drive to achieve' (12-14)). This constructs Kate's cognitive processes resulting in her having more resilience, 'come back fighting' (13) and this is emphasised through the prior talk about her socio-economic position. Like the previous extracts, Kate presents herself as being more driven, 'drive to achieve' (13-14). Kate orients to these extraordinary characteristics to justify the accumulation of her wealth and her current status as a super-rich individual.

In Kate's construction of her pursuit of wealth, she presents herself as having increased resilience which she evidences through her increased levels of activity over a long-term period. She presents herself as being hardworking ('So I started off as a secretary and then I went and done me education as well at the same time' (16-18)). Whilst this involves the use of an 'effortfulness' interpretative repertoire (Gibson, 2009), Kate has an increased level of effortfulness that results in her becoming superrich which is built up through the extract ('I was a single mum, I was working fulltime, and I was doing you know a degree as well' (18-19)). Whilst the category of 'single mother' can be used to present women as having poor moral standards (Stokoe, 2003), here it is used to construct a 'super mom' who has both a paid working and unpaid mothering role (Jackson and Gee, 2005). The use of a gender role in talk allows Kate to present her moral position (Stokoe and Edwards, 2012). This constructs Kate as being more than effortful as she carried out three roles when in everyday talk one of these roles would be considered a sufficient use of time for a person. This demonstrates her resilience and drive to the audience justifying her wealth through her superior traits. The change in pronouns from 'I' to 'you' allows Kate's activities to appear as natural and every day, the result of her psychological construction and possible for others to achieve ('then I invested me money correctly and then you built up your own empire' (21-22)). This also allows Kate through the use of 'you' (22) to warrant her wealth generation as something that anybody could achieve. Eamonn reinforces Kate's presentation by using a three-part list (Jefferson, 1990) that is more specific than Kate's description of an 'empire' (22) ('Kate eventually made her millions by building up a series of markets, tanning shops, and beauty salons' (23-25)). By being more specific, Eamonn upgrades Kate's attempts to manage the modest construction of herself as having superior psychological abilities naturally. Eamonn's statement is not delivered to Kate directly. His talk is delivered via a voiceover and the camera is zoomed out and out of focus emphasising his statement to the audience about Kate's success as a result of her increased resilience. Kate's accumulation of wealth to her super-rich status is presented as the outcome of a natural progression given the use of a 'rags to riches' interpretative repertoire.

Kate uses talk of her achievements as the result of her increased resilience and drive to justify her super-rich status that allows her to be constructed as deserving of her wealth. In the next extract, the speakers talk about resilience being needed to maintain wealth. Unlike the previous extract where Kate required resilience to acquire her wealth, here resilience is needed for the maintenance of wealth. The following extract is also 
taken from Eamonn and Ruth: How the Other Half Lives (series two, episode two), a Channel 5 series featuring in this episode Eamonn Holmes (E) and Ruth Langsford (R) as presenters talking to David Sullivan (D) who is introduced as a 'billionaire who lives like a King'. This segment takes place in David's office with Ruth and Eamonn sat talking to him around his desk. This provides the opportunity to examine the talk of the super-rich to examine how the super-rich talk about their resilience in relation to maintaining their wealth.

Extract four:

1. D: This is my little office, have a sit down.

2. R: Your little office!

3. D: No, it is little. It isn't very big.

4. R: It's as big as my downstairs!

5. E: ((footage of Oxford Street)) It's from here David oversees

$6 . \quad$ countless employees, his vast property portfolio and an eye-

$7 . \quad$ watering amount of investments.

8. D: This is where I try and make some money every day.

9. E: Yeah. Do you make money every day? Do you set out to make

10. money?

11. D: Not every day. I've had some terrible days. When things

12. crashed in 2007, you know, that was scary times. It was like the

13. end of the world. There was days I was losing $£ 10$ million a

14. day.

15. R: Wow.

16. D: And your family say, "Oh, you're a bit down today, Dad." I said,

$17 . \quad$ well, you know

18. R: Just lost ten million quid.

19. D: You drop 100 million quid in a month, it's going to depress you,

20. so it's good days and bad days.

Prior to discussing David's resilience, the extract highlights David's position as super-rich and presenting him as being driven. His position is established using a three-part list by Eamonn ('It's from here David oversees countless employees, his vast property portfolio and an eye-watering amount of investments' (5-7)). The use of a three-part list by Eamonn highlights David's 'effortfulness' (Gibson, 2009) and by being provided through a voiceover presents a clear contrast to David's downgrading of his efforts with the use of 'I try' (8). David constructs himself as being active in the generation of further wealth. Yet, this presentation is managed by David as he ignores Eamonn's second question (Yeah. Do you make money every day? Do you set out to make money? (9-10)). Whilst the speakers present super-rich drive as acceptable, the active pursuit of wealth is more problematic and is dealt with by David not responding to the second question allowing David to manage his accountability for his wealth through this absence as he does not have to reveal his stake (Potter, 1996). Here, David ignoring the question reveals that there is a norm against being openly motivated to acquire wealth.

This extract demonstrates that David requires resilience to maintain his wealth, which differs from extract three where this trait was used for its acquisition. By referring to the 
Global Financial Crisis, David draws upon a shared experience that requires resilience ('Not every day. I've had some terrible days. When things crashed in 2007, you know, that was scary times' (11-12)). This is differentiated from others' experiences by a specific reference to the amount of his losses ('There was days I was losing $£ 10$ million a day' (13-14)). By specifically referring to a large amount of money being lost daily, David highlights the risks of being super-rich and the superior resilience required to manage this type of loss as an entrepreneur. However, by drawing upon his role as a father, David is able to orient to his resilience in addition to a shared experience that is relatable to the audience ("And your family say, "Oh, you're a bit down today, Dad." I said, well, you know' (16-17)). The use of this places David as requiring resilience to manage not just his wealth but his role as a parent which is an everyday presentation. The use of talk about parenting allows David to be presented as an ordinary person with everyday issues. David continues to present himself as resilient using psychological language by referring to depression (19-20). David presents himself as being resilient to the challenges of being super-rich.

\section{Discussion}

The findings demonstrate that entertainment documentaries present super-rich individuals as being psychologically different to most people due to their increased resilience and drive. This draws upon an individualistic argument that presents wealthy people's privilege as meritocratic. Speakers' claims of psychological superiority allow them to legitimise the acquisition and maintenance of their wealth. Examples of drive are present throughout the extracts and are used to argue that the wealthy are more effortful than others. Within wealth porn programming, the earning of wealth is constructed as achievable by anyone who has sufficient drive. This is emphasised through the final speaker's psychological superiority as a response to the challenging circumstances of lone parenthood and poor start in life. Super-rich individuals are presented as both ordinary and extraordinary and thus, deserving of their wealth. Due to their ordinariness, affluence is warranted as accessible to anyone to legitimise inequality in society as others are not effortful enough. This draws upon individualistic ideology such as just world arguments (Goodman and Carr, 2017) and wealth as earned by individuals not the result of collective effort (Carr, 2020). The use of individualistic ideology presents the super-rich in entertainment documentaries as deserving in a meritocratic environment due to their increased skills and work ethic.

\section{Using resilience to legitimise wealth}

The construction of the super-rich as being psychologically different accounts for wealth inequality as a consequence of legitimising extreme wealth acquisition. This is also achieved in talk about tax that challenges calls to redistribute wealth to reduce poverty and increase access to public resources to those in need (Carr et al., 2019). In the data, superior resilience is used in talk to legitimise their wealth and to position it as attainable for others. Resilience is currently a popular and pervasive concept in everyday talk and within policy (McNamee et al., 2014) as reflected in its inclusion in the 
educational curriculum (Clarke, 2015). Whilst the employed use an 'effortfulness' interpretive repertoire (Gibson, 2009), the super-rich present themselves as exceptionally effortful in relation to their levels of economic activity. Individuals who are not as economically active due to their lower levels of resilience are considered to have failed (Windle, 2010). Talk about resilience allows economic inequality in society to be considered inevitable (Clarke, 2015). This is reflected in discourse about benefit claimants on television who are presented as lacking behaviours that are exhibited by workers and are thus, deserving of their poverty (Goodman and Carr, 2017). The use of individualised explanations, using psychological terms such as traits, for wealth distribution in society legitimises the privilege of the super-rich.

\section{Drive: Wealth acquisition as innate}

Talk about drive by super-rich individuals legitimises their wealth by drawing upon individual differences that are both innate and extraordinary. Individual differences are socially constructed and are used by speakers to justify their position in presenting their wealth as deserved. As a result, talk about drive uses individualistic ideology formed of everyday assumptions that is difficult for individuals to challenge (Billig, 1997). Yet, speakers orient to others' negative orientations for their drive such as greed. By presenting their drive as innate, super-rich people can challenge arguments that criticise the accumulation of extreme wealth. This provides the super-rich with the opportunity to present their drive to be economically active as natural.

The super-rich present themselves as having an innate drive to acquire wealth as the motive behind the achievement of their status and to legitimise their economic activity in an unequal society. Motives are discursive devices that are used in everyday talk (Roth and Hsu, 2008). People use talk about motives to manage their discourse with others (Fogarty and Augoustinos, 2008). Edwards (1998) states that individuals can orient to their identity to negotiate their accountability within talk. A 'rags to riches' interpretative repertoire is used to present increased drive as a natural response to adversity that others could emulate. Drive is also warranted as a response to having low selfworth. This allows super-rich speakers to present their drive as positive and the negative effects of inequality as the responsibility of the poor for being inactive due to their lack of drive. However, speakers do not explicitly mention economic inequality in their talk. Thus, by not orienting to inequality super-rich individuals are able to justify their drive and to legitimise their wealth in the context of wealth inequality and its negative impact upon others.

Talk about drive by super-rich individuals accounts for their wealth by drawing upon individual differences that are innate or acquired, and extraordinary. Individual differences are socially constructed and are used by speakers to justify their position in presenting their wealth as deserved. As a result, talk about drive uses individualistic ideology that is formed of everyday assumptions that is difficult for individuals to challenge (Billig, 1997). Some speakers orient to other possible explanations for their wealth such as greed. However, the presentation of drive as something that can be acquired in response to difficult circumstances such as lone parenthood, wealth can also be warranted as available for others who are prepared to exhibit superior levels of effortfulness. 
This provides the super-rich with the opportunity to present their drive to be economically active as potentially attainable to all. Within the programmes, wealth distribution is presented as an individual and not a collective issue that is mediated by a person's skills and abilities in an allegedly meritocratic environment.

\section{Conclusion}

Wealth porn programming constructs the super-rich as being both psychologically superior to others and ordinary to legitimise their wealth. By drawing upon the traits of resilience and drive in their talk, the super-rich are able to present themselves as being different to others. However, speakers also draw upon relatable experiences to the audience such as global events or mental health issues to be both normal and superior. Entertainment documentaries legitimise the wealth of the super-rich as being natural as a result of their differing psychological construction. The super-rich are also presented as ordinary and their wealth as accessible to those who can acquire their drive. As a result, the presence of economic inequality in society is presented as common sense. The use of individual ideology to account for wealth inequality is pervasive and prevents a damaging social problem from being addressed collectively.

\section{Declaration of conflicting interests}

The author(s) declared no potential conflicts of interest with respect to the research, authorship, and/or publication of this article.

\section{Funding}

The author(s) disclosed receipt of the following financial support for the research, authorship, and/ or publication of this article: by the Coventry University.

\section{References}

Abell J and Stokoe EH (2001) Broadcasting the royal role: Constructing culturally situated identities in the Princess Diana Panorama interview. British Journal of Social Psychology 40(3): $417-435$.

Allen A (2011) Michael Young's the rise of the meritocracy: A philosophical critique. British Journal of Educational Studies 59(4): 367-382.

Billig M (1987) Arguing and Thinking: A Rhetorical Approach to Social Psychology. Cambridge, MA: Cambridge University Press.

Billig M (1991) Ideology and Opinions: Studies in Rhetorical Psychology. London: SAGE.

Billig M (1992) Talking of the Royal Family. London: Routledge.

Billig M (1997) Discursive, rhetorical and ideological messages. In: McGarty C and Haslam SA (eds) The Message of Social Psychology. Oxford: Blackwell, pp.36-53.

Billig M (2005) Laughter and Ridicule: Towards a Social Critique of Humour. London: SAGE.

Burr V (2015) Social Constructionism, 3 edn. Hove: Routledge.

Carr P (2020) Extending the boundaries of political communication: How ideology can be examined in super-rich television documentaries using Discursive Psychology. In: Tileagă C, Burke S and Demasi M (eds) Political Communication: Discursive Perspectives. London: Palgrave Macmillan, pp.89-114. 
Carr P, Goodman S and Jowett A (2019) 'I don't think there is any moral basis for taking money away from people': Using discursive psychology to explore the complexity of talk about tax. Critical Discourse Studies 16(1): 84-95.

Clarke C (2015) Learning to fail: Resilience and the empty promise of financial literacy education. Consumption Markets and Culture 18(3): 257-276.

Condor S, Tileagă C and Billig M (2013) Political rhetoric. In: Huddy L, Sears DO and Levy JS (eds) Oxford Handbook of Political Psychology. Oxford: Oxford University Press, pp.262-300.

Connor KM and Davidson JRT (2003) Development of a new resilience scale: The ConnorDavidson Resilience Scale (CD-RISC). Depression and Anxiety 18(2): 76-82.

Davies B and Harré R (1990) Positioning: The discursive production of selves. Journal for the Theory of Social Behaviour 20(1): 43-63.

Day K (2020) Social class: What is it and why does it matter? In: Day K, Rickett B and Woolhouse M (eds) Critical Social Psychology of Social Class. London: Palgrave Macmillan, pp.1-31.

Day K, Rickett B and Woolhouse M (2014) Class dismissed: Putting social class on the critical psychological agenda. Social and Personality Psychology Compass 8(8): 397-407.

De Vos J (2008) From panopticon to pan-psychologisation or, why do so many women study psychology? International Journal of Žižek Studies 2(1): 1-20.

Dirzytė A, Rakauskienė OG and Servetkienè V (2017) Evaluation of resilience impact on socioeconomic inequality. Entrepreneurship and Sustainability Issues 4(4): 489-501.

Edley N and Wetherell M (1997) Jockeying for position: The construction of masculine identities. Discourse \& Society 8(2): 203-217.

Edwards D (1998) The relevant thing about her: Social identity categories in use. In: Antaki C and Widdicombe S (eds) Identities in Talk. London: SAGE, pp.15-33.

Edwards D and Potter J (1992) Discursive Psychology. London: SAGE.

Eysenck HJ (1975) The Inequality of Man. London: Pan.

Fogarty K and Augoustinos M (2008) Feckless fathers and monopolizing mothers: Motive, identity, and fundamental truths in the Australian Public Inquiry into Child Custody. British Journal of Social Psychology 47(3): 535-556.

Gibson S (2009) The effortful citizen: Discursive social psychology and welfare reform. Journal of Community \& Applied Social Psychology 19(6): 393-410.

Goffman E (1981) Frames of Talk. Philadelphia, PA: University of Pennsylvania Press.

Goodman S and Carr P (2017) Belief in a Just World as an argumentative resource in debates about unemployment benefits. Journal of Community \& Applied Social Psychology 27(4): $312-323$.

Gottfredson LS (2016) Hans Eysenck's theory of intelligence, and what it reveals about him. Personality and Individual Differences 103: 116-127.

Grant AM, Curtayne L and Burton G (2009) Executive coaching enhances goal attainment, resilience and workplace well-being: A randomised controlled study. The Journal of Positive Psychology 4(5): 396-407.

Hester H (2014) Weaponizing prurience. In: Korte B and Regard F (eds) Narrating Poverty and Precarity in Britain. Berlin: De Gruyter, pp.205-224.

Hunt MO (2004) Race/ethnicity and beliefs about wealth and poverty. Social Science Quarterly 85(3): 827-853.

Iatridis T and Fousiani K (2009) Effects of status and outcome on attributions and just-world beliefs: How the social distribution of success and failure may be rationalized. Journal of Experimental Social Psychology 45(2): 415-420.

Jackson S and Gee S (2005) 'Look Janet', 'No you look John': Constructions of gender in early school reader illustrations across 50 years. Gender and Education 17(2): 115-128. 
Jefferson G (1990) List construction as a task and resource. In: Psathas G (ed.) Interaction Competence. Washington: International Institute for Ethnomethodology and Conversation Analysis and University Press America, pp.63-92.

Jefferson G (2004) Glossary of transcript symbols with an introduction. In: Lerner GH (ed) Conversation Analysis: Studies from the First Generation. Amsterdam: John Benjamin, pp.13-31.

Leahy RL (1981) The development of the conception of economic inequality. I. Descriptions and comparisons of rich and poor people. Child Development 52(2): 523-532.

Lerner MJ (1980) The Belief in a Just World: A Fundamental Delusion. London: Plenum Press.

Leudar I and Antaki C (1996) Discourse participation, reported speech and research practices in social psychology. Theory \& Psychology 6(1): 5-29.

McNamee SJ and Miller RK Jr (2014) The Meritocracy Myth, 3rd edn. Plymouth: Rowman and Littlefield.

Olick JK (2016) The poverty of resilience: On memory, meaning, and well-being. Memory Studies 9(3): 315-324.

Oxford English Dictionary (2010) OED, 3rd edn. Oxford: Oxford University Press.

Poole GA (2000) "Wealth porn” and beyond. Columbia Journalism Review 39(4): 22-23.

Potter J (1996) Representing Reality: Discourse, Rhetoric and Social Construction. London: SAGE.

Rickett B (2020) Psychology and social class: The working class as 'other'. In: Day K, Rickett B and Woolhouse M (eds) Critical Social Psychology of Social Class. London: Palgrave Macmillan, pp.33-66.

Robertson I and Cooper CL (2013) Resilience. Stress and Health 29: 175-176.

Roth W-M and Hsu P-L (2008) Interest and motivation: A cultural-historical and discursive psychological approach. In: Larson JE (ed.) Cognition and Learning, Individual Differences and Motivation. New York: Nova Science Publishers.

Smith JF and Skrbiš Z (2017) A social inequality of motivation? The relationship between beliefs about academic success and young people's educational attainment. British Educational Research Journal 43: 441-465.

Snibbe AC and Markus HR (2005) You can't always get what you want: Educational attainment, agency, and choice. Journal of Personality and Social Psychology 88(4): 703-720.

Stokoe EH (2003) Mothers, single women and sluts: Gender, morality and membership categorization in neighbour disputes. Feminism \& Psychology 13(3): 317-344.

Stokoe EH and Edwards D (2012) Mundane morality: Gender, categories and complaints in familial neighbour disputes. Journal of Applied Linguistics and Professional Practice 9(2): $165-192$.

Urry J (2014) Offshoring. London: Polity.

Vansteenkiste M and Mouratidis A (2016) Emerging trends and future directions for the field of motivation psychology: A special issue in honor of Prof. Dr. Willy Lens. Psychologica Belgica 56(3): 317-341.

Wai J (2014) Investigating the world's rich and powerful: Education, cognitive ability, and sex differences. Intelligence 46: 54-72.

Wetherell M (1998) Positioning and interpretative repertoires: Conversational analysis and poststructuralism in dialogue. Discourse \& Society 9(3): 387-412.

Wetherell M and Potter J (1988) Discourse analysis and interpretative repertoires. In: Antaki C (ed.) Analysing Everyday Explanation: A Casebook of Methods. London: SAGE, pp.156-183.

Wiggins S (2017) Discursive Psychology. London: SAGE.

Wilkinson R and Pickett K (2010) The Spirit Level: Why Equality is Better for Everyone. London: Penguin Books. 
Windle G (2010) What is resilience? A review and concept analysis. Reviews in Clinical Gerontology 21(2): 152-169.

Young M (1958) The Rise of the Meritocracy. London: Thames and Hudson.

Zhao K, Ferguson E and Smillie LD (2016) Prosocial personality traits differentially predict egalitarianism, generosity, and reciprocity in economic games. Frontiers in Psychology 7(1137): $1-18$.

\section{Author biographies}

Dr Philippa Carr is a Senior Lecturer in Qualitative Research Methods at the University of the West of England. She is interested in the use of Discursive Psychology to explore talk in the media about wealth inequality.

Dr Simon Goodman is a Senior Lecturer in Psychology at De Montfort University. He uses discursive and rhetorical psychology to address a number of issues including the discursive construction of asylum seekers and refugees, race talk and income inequality. He is a committee member of the British Psychological Society's Qualitative Methods in Psychology and Social Psychology Sections and co-author of The Language of Asylum published by Palgrave.

Dr Adam Jowett is an Associate Head of the School of Psychological, Social \& Behavioural Sciences at Coventry University. His research interests cohere around social inequalities, particularly for lesbian, gay, bisexual and trans (LGBT) people. His previous research has explored how marriage inequality is rhetorically justified within the media. He is an Associate Editor for the journal Psychology \& Sexuality.

Dr Jackie Abell is an Associate Professor in Psychology within the Centre for Agroecology, Water $\&$ Resilience situated at Coventry University. Her research interests centre around the application of social psychological knowledge to issues surrounding social inclusion, exclusion, environmental sustainability and wildlife conservation. She is the lead author of the David Myers Social Psychology textbook and an Associate Editor for the British Journal of Social Psychology.

\section{Appendix}

\section{Guide for transcription}

(.)

(h)

Micro pause

(unknown)

A longer pause measured in tenths of a second

((context))

Laughter

[interrupt]

Audio indecipherable or unclear

italics

of camera angles

Speakers talk overlaps

Taken from Jefferson (2004) except for notations* 